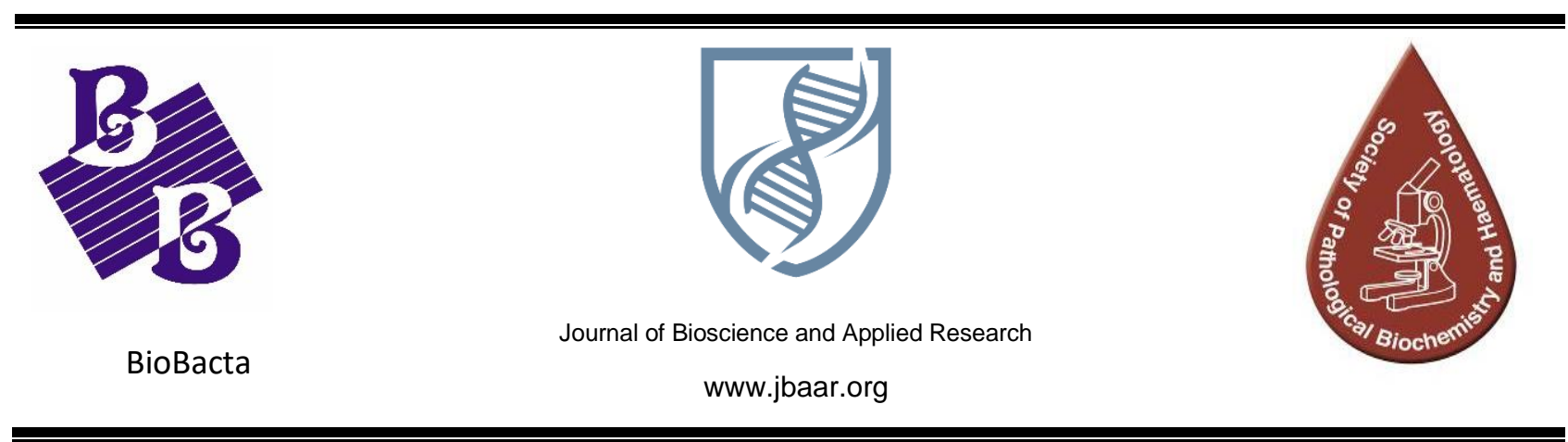

\title{
B Cell Lymphoma-2 (Bcl-2) in Serum Increased with Breast Cancer in Egyptian Women
}

\author{
Ali Ahmad Abu Siyam ${ }^{1 *}$, Soheir Rizk Demian², Ahmed Saad Ahmed ${ }^{3}$, \\ Mohammad Abdel- Rhman Ahmad ${ }^{4}$ and Basma Hussein Mersal ${ }^{2}$. \\ ${ }^{1}$ Department of Medical Laboratory Sciences, Faculty of Pharmacy, Jadara University, Jordan. \\ ${ }^{2}$ Department of Immunology and Allergy, Medical Research Institute, University of Alexandria. Egypt. \\ ${ }^{3}$ Department of Clinical and Experimental Surgery, Medical Research Institute, University of Alexandria, \\ Egypt \\ ${ }^{4}$ Department of Clinical Pathology and Immunology, Medical Military Academy, Alexandria Armed Forces \\ Hospital, Egypt \\ * Corresponding author: Ali Ahmad Abu Siyam. Email: aabusiyam@jadara.edu.jo
}

DOI: 10.21608/jbaar.2018.155808

\begin{abstract}
Breast cancer is the most commonly diagnosed female-specific cancer and shows an increasing trend in diagnosed cases worldwide. An estimated one in eight women will develop breast cancer in her lifetime. $\mathrm{BC}$ is estimated to be the most common female cancer in Egypt, and the incidence rate among Egyptian women is $48.8 / 10^{5}$. Evasion of cell death is now acknowledged as a hallmark of cancer, required to overcome the counterbalancing effects of cell death on enhanced cell proliferation. B cell lymphoma-2 (Bcl-2) gene involves in cell survival mechanism rather than cell proliferation and it prolongs cell life by preventing apoptosis via activating different signaling routes which are induced by various agents. We aimed in this study to investigate whether the Bcl-2 activities are associated with breast cancer in Egyptian women, and correlated to different clinicopathological features of the disease. The study was conducted on forty-five females; thirty women with different stages of breast cancer, and fifteen normal healthy females were included as a control group. All patients under study were subjected to full history taking and clinical examination. Fresh blood samples were obtained from all subjects, serum separation was done for measurement of Bcl-2 levels by ELISA technique. Our results showed that there were significantly higher serum Bcl-2 levels in breast cancer patients before surgery than in normal healthy controls. The results obtained also revealed that the mean value of Bcl-2 for the breast cancer patients was significantly higher than the control group. We almost can say that the Bcl-2 values would increase with advanced stages of breast cancer.
\end{abstract}

Keywords: B cell lymphoma-2 (Bcl-2), Breast cancer, Egyptian women. 


\section{Introduction}

Cancer can be viewed as the result of a succession of genetic changes during which a normal cell is transformed into a malignant one while evasion of cell death is one of the essential changes in a cell that cause this malignant transformation ${ }^{(1)}$. As early as the 1970's, Kerr et al had linked apoptosis to the elimination of potentially malignant cells, hyperplasia, and tumor progression ${ }^{(2,3)}$. Hence, reduced apoptosis or its resistance plays a vital role in carcinogenesis. There are many ways a malignant cell can acquire a reduction in apoptosis or apoptosis resistance. Generally, the mechanisms by which evasion of apoptosis occurs can be broadly divided into 1) disrupted the balance of pro-apoptotic and antiapoptotic proteins (Bcl-2), 2) reduced caspase function, and 3) impaired death receptor signaling (4).

Bcl-2 was the first protein of this family to be identified more than 20 years ago and it is encoded by the $\mathrm{Bcl}-2$ gene, which derives its name from B-cell lymphoma 2, the second member of a range of proteins found in human B-cell lymphomas with the $\mathrm{t}(14 ; 18)$ chromosomal translocation. All the Bcl-2 members are located on the outer mitochondrial membrane. They are dimmers that are responsible for membrane permeability either in the form of an ion channel or through the creation of pores ${ }^{(5)}$.

Apoptosis within the breast occurs with each hormonal cycle throughout a woman's reproductive lifespan ${ }^{(6)}$. Some investigators demonstrated that Bcl-2 family proteins are key regulators of cell survival during lactation and are critical for inducing cell death of the milk-producing epithelium once lactation ceases ${ }^{(7)}$. Less is known regarding the $\mathrm{Bcl}-2$ family in the lobular (menopausal) involution of the breast. However, increasing evidence suggests that the extent to which lobular involution occurs is directly proportional to a woman's risk of developing postmenopausal breast cancer. Nearly $70 \%$ of all breast cancers occur in post-menopausal women. It is therefore important to understand the molecular mechanisms contributing to lobular involution. Given the importance of Bcl-2 proteins in other stages of breast development, these observations support the exploration of Bcl-2 family proteins in lobular involution ${ }^{(6)}$. However, Bcl-2 and Bcl-xL overexpression in combination with oncogeneinduced proliferation resulted in lumen filling, a morphological characteristic of DCIS, an early premalignant state, and these findings demonstrated that pro-proliferative and anti-apoptotic signals cooperate in early MEC transformation and that anti-apoptotic Bcl-2 proteins contribute to this process ${ }^{(8)}$.

Resistance to antigrowth stimuli is the major hallmark of cancer cells which is due to the overexpression of antiapoptotic Bcl-2 proteins. The overexpression of $\mathrm{Bcl}-2$ family proteins also contributes to the resistance and recurrence of cancer ${ }^{(9)}$. Bcl-2 family proteins also mediate resistance to targeted breast cancer therapies. The anti-HER2 antibody, trastuzumab, is clinically approved for use in $20 \%$ of all breast cancers that exhibit HER2 gene amplification. However, many HER2-amplified tumors display innate trastuzumab resistance, while others rapidly acquire trastuzumab resistance. Trastuzumab-resistant HER2+ breast cancer cell lines frequently upregulate Bcl-2 and decrease Bax as a means of enhancing cell survival (10).

\section{Materials and Methods}


This study was conducted on thirty women with different stages of confirmed breast cancer recruited from the Clinical and Experimental Surgery Department, Medical Research Institute, Alexandria, Egypt. Fifteen ages matched normal healthy individuals were also included as a control group. All individuals under study were subjected to the following: Full History taking, clinical examination, radiological investigations, and histopathological examination. A venous blood sample was collected from each participant into a serum separator tube. Serum separation was done by centrifugation at $4000-5000 \mathrm{rpm} / \mathrm{min}$ for 5 minutes. Analysis of circulating levels of Bcl-2 in serum samples was done by ELISA technique according to Bender MedSystems GmbH (eBioscience), 2015 manufacturer ${ }^{(11)}$. An anti-human Bcl-2 coating antibody is adsorbed onto microwells. Human Bcl2 present in the sample or standard binds to antibodies adsorbed to the microwells. The absorbance of each microwell was read on a spectrophotometer using $450 \mathrm{~nm}$ as the primary wavelength. The plate reader was blanked by using the blank walls. The absorbance of both the samples and the standards were determined. The average absorbance values were calculated for each set of duplicate standards and samples. A standard curve was created by plotting the mean absorbance for each standard concentration on the ordinate against the human Bcl-2 concentration on the abscissa. A best-fit curve was drawn through the points of the graph. The concentration of circulating human Bcl2 was determined for each sample by found the mean absorbance value on the ordinate and extends a horizontal line to the standard curve. At the point of intersection, a vertical line was extended to the abscissa and read the corresponding human Bcl-2 concentration. Data were fed to the computer using IBM SPSS software package version 20.0. Quantitative data were described using mean and standard deviation for normally distributed data while abnormally distributed data were expressed using a range.

\section{Results:}

\section{Clinicopathological features of the patients:}

Age

The age range in the breast cancer patient group was 21-75 years with a mean $+\mathrm{SD}$ of $51.3 \pm 12.86$, while it was $26-62$ years in a control group with a mean $\pm \mathrm{SD}$ of $47.8 \pm 9.30$. There is no significant difference between the mean age values of the two studied groups (Table 1).

Table (1): Age distribution of studied groups.

\begin{tabular}{lll}
\hline Age (years) & $\begin{array}{l}\text { Breast cancer } \\
(\mathbf{n = 3 0})\end{array}$ & $\begin{array}{l}\text { Control } \\
(\mathbf{n = 1 5})\end{array}$ \\
\hline Range & $21-75$ & $26-62$ \\
Mean & 51.3 & 47.8 \\
Std. Deviation (SD) & 12.86 & 9.30 \\
\hline
\end{tabular}




\section{Menopausal status}

The menopausal status of all subjects under study is summarized in table (2). In the breast cancer group, 13 out of 30 patients were premenopausal
(43.3\%) while 17 were postmenopausal $(56.7 \%)$. In the control group, 10 out of 15 females were premenopausal $(66.7 \%)$ while 5 were postmenopausal $(33.3 \%)$.

Table (2): Menopausal status among studied groups.

\begin{tabular}{lllll}
\hline Menopausal status & \multicolumn{2}{l}{$\begin{array}{l}\text { Breast cancer } \\
(\mathbf{n = 3 0})\end{array}$} & \multicolumn{2}{l}{$\begin{array}{l}\text { Control } \\
(\mathbf{n = 1 5})\end{array}$} \\
\hline & No. & $\%$ & No. & $\%$ \\
Pre-menopausal & 13 & 43.3 & 10 & 66.7 \\
Post-menopausal & 17 & 56.7 & 5 & 33.3 \\
\hline
\end{tabular}

\section{Family History for breast cancer}

The family history of all subjects under study is summarized in table (3). In the breast cancer patient group 14 patients had a positive family history of breast cancer (46.7\%) where are 16 had a negative family history $(53.3 \%)$, while in the control group 2 females had a family history of breast cancer (13.3\%) and 13 had no family history to the disease $(86.7 \%)$.

Table (3): Family History for breast cancer among studied groups

\begin{tabular}{lllll}
\hline $\begin{array}{c}\text { Family History for } \\
\text { breast cancer }\end{array}$ & \multicolumn{2}{l}{$\begin{array}{l}\text { Breast cancer } \\
(\mathbf{n}=30)\end{array}$} & \multicolumn{2}{l}{$\begin{array}{l}\text { Control } \\
(\mathbf{n = 1 5})\end{array}$} \\
& No. & $\%$ & No. & $\%$ \\
\hline Positive & 14 & 46.7 & 2 & 13.3 \\
Negative & 16 & 53.3 & 13 & 86.7 \\
\hline
\end{tabular}

\section{Hormone Replacement Therapy (HRT) use}

In breast cancer patients, 13 out of 30 HRT used (43.3\%) and 17 out of 30 not used (56.7 \%) (Table 4).

Table (4): HRT used by breast cancer patient group.

\begin{tabular}{llll}
\hline & HRT & \multicolumn{2}{l}{$\begin{array}{l}\text { Breast cancer } \\
(\mathbf{n}=30)\end{array}$} \\
& No. & $\%$ \\
\hline Used & 13 & 43.3 \\
Not used & 17 & 56.7 \\
\hline
\end{tabular}




\section{Histopathological tumor type}

According to the results of histopathological examination; in breast cancer patients, 17 patients had DCIS type (56.7\%) and 13 had IDC (43.3\%) (Table 5).

Table (5): Distribution of the breast cancer patients according to histopathological type.

\begin{tabular}{|c|c|c|}
\hline \multirow[t]{2}{*}{ Histological tumor type } & \multicolumn{2}{|c|}{$\begin{array}{l}\text { Breast cancer } \\
(\mathbf{n}=\mathbf{3 0})\end{array}$} \\
\hline & No. & $\%$ \\
\hline Ductal carcinoma in situ (DCIS) & 17 & 56.7 \\
\hline Infiltrated Ductal Carcinoma (IDC) & 13 & 43.3 \\
\hline Other types & 0 & 0 \\
\hline Unknown & 0 & 0 \\
\hline
\end{tabular}

Tumor grade

In the patient's group, 15 cases were found to be grade I (50\%), 5 cases were grade II (16.7 \%), 6 cases were grade III ( $20 \%$ ), and 4 cases unknown grade (13.3\%), while neither of them was at grade IV (Table 6).

Table (6): Distribution of the breast cancer patient cases according to tumor grade.

\begin{tabular}{lll}
\hline & Tumor grade & $\begin{array}{l}\text { Breast cancer } \\
(\mathbf{n = 3 0})\end{array}$ \\
& No. & $\%$ \\
\hline I & 15 & 50 \\
II & 5 & 16.7 \\
III & 6 & 20 \\
IV & 0 & 0 \\
Unknown & 4 & 13.3 \\
\hline
\end{tabular}

\section{Estrogen Receptor/ Progesteron Receptor (ER/PR) expression}

Immunohistochemical (IHC) analysis revealed that 13 patients had positive ER/PR (43\%), 13 had negative ER/PR (43.3\%), and 4 were unknown results (13.3\%) (Table 7). 
Table (7): ER/PR expression in breast cancer patient group.

\begin{tabular}{lll}
\hline & ER/PR expression & \multicolumn{2}{l}{ Breast cancer } \\
& $(\mathbf{n = 3 0})$ & \\
& No. & $\%$ \\
\hline Positive & 13 & 43.3 \\
Negative & 13 & 43.3 \\
Unknown & 4 & 13.3 \\
\hline
\end{tabular}

Human Epidermal Growth Factor Receptor 2 (HER-2) expression

Immunohistochemical (IHC) analysis revealed that 10 patients had positive HER-2 (33.3\%), 16 had negative HER-2 (53.3\%), and 4 were unknown results (13.3\%) (Table 8).

Table (8): HER-2 expression in breast cancer patient group.

\begin{tabular}{lll}
\hline & HER-2 expression & $\begin{array}{l}\text { Breast cancer } \\
(\mathbf{n = 3 0})\end{array}$ \\
& No. & $\%$ \\
\hline Positive & 10 & 33.3 \\
Negative & 16 & 53.3 \\
Unknown & 4 & 13.3 \\
\hline
\end{tabular}

\section{Bcl-2 levels:}

The mean $\pm \mathrm{SD}$ for Bcl-2 values were $2.01 \pm 1.91$ and $1.17 \pm 0.17$ in breast cancer and control groups, respectively. The mean Bcl-2 level was significantly $(\mathrm{p}=0.025)$ increased in breast cancer patients when compared to the control group (Table 9).

Table (9): Bcl-2 levels of studied groups.

\begin{tabular}{lcll}
\hline $\begin{array}{l}\text { Bcl-2 levels } \\
(\mathbf{n g} / \mathbf{m l})\end{array}$ & $\begin{array}{c}\text { Breast cancer } \\
(\mathbf{n = 3 0})\end{array}$ & $\begin{array}{c}\text { Control } \\
(\mathbf{n = 1 5})\end{array}$ & p-value* \\
\hline Range & $1.0-10.0$ & $0.75-1.4$ & 0.025 \\
Mean & 2.0050 & 1.1733 & \\
Std. Deviation $(\mathrm{SD})$ & 1.91 & 0.17 & \\
\hline Significant at $\mathrm{p} \leq 0.05$ level & &
\end{tabular}


Bcl-2 levels and clinicopathological features of breast cancer patients:

Table (10) summarizes Bcl-2 levels and clinicopathological parameters in breast cancer patients. Our data revealed that there was a significant difference in the mean values of Bcl-2 in the different clinicopathological parameters.

Statistical analysis of results indicated that there was a significant increase in the mean value $\mathrm{Bcl}-2$ in patients $\geq 50$ years than $<50$ years $(\mathrm{p}=<0.005)$, in postmenopausal than premenopausal $(p=0.006)$, in -ve family history than $+\mathrm{ve}(\mathrm{p}=<0.005)$, in not used HRT than HRT used $(\mathrm{p}=<0.005)$ and in IDC patients than DCIS patients $(\mathrm{p}=<0.005)$. Also, it was found that there was a significant increase in the mean values of $\mathrm{Bcl}-2$ for grade III than grade I\&II $(p=0.05)$. We almost can say that the Bcl-2 values would increase with advanced stages of breast cancer. Also, it was observed that there was a significant increase in mean values of $\mathrm{Bcl}-2$ in patients with -ve ER/PR and Her-2 expression than + ve expression patients $(\mathrm{p}=<0.005)$.

Table (10): Bcl-2 levels and clinicopathological features of breast cancer patients.

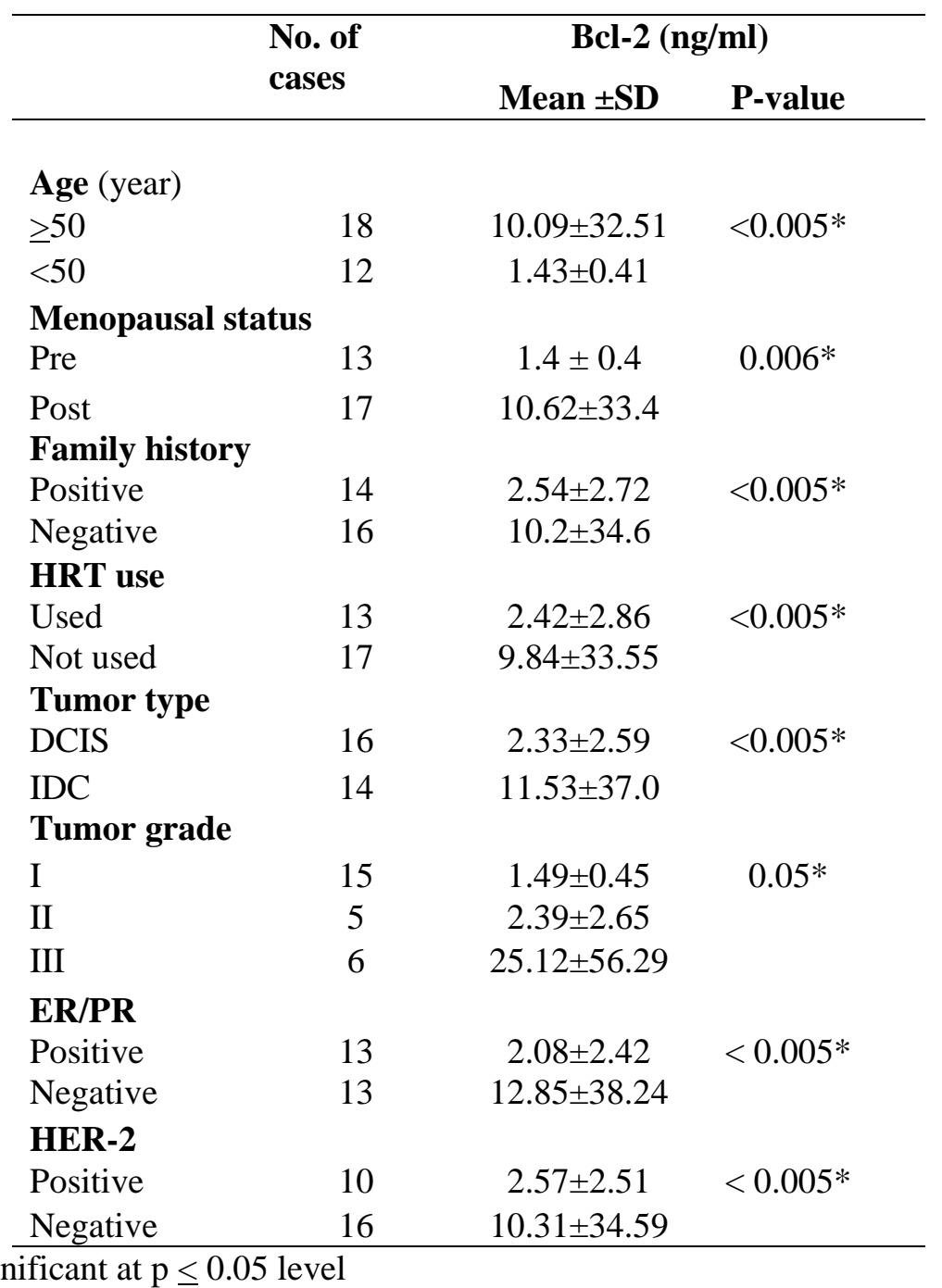

$*$ significant at $\mathrm{p} \leq 0.05$ level 


\section{Discussion}

Evasion of cell death is now acknowledged as a hallmark of cancer, required to overcome the counterbalancing effects of cell death on enhanced cell proliferation ${ }^{(12)}$. Bcl-2 gene involves in cell survival mechanism rather than cell proliferation and it prolongs cell life by preventing apoptosis via activating different signaling routes which are induced by various agents ${ }^{(13)}$.

In the present work, there were significantly higher serum Bcl-2 levels in breast cancer patients before surgery than in normal healthy controls. The mean $\pm \mathrm{SD}$ value for the breast cancer group was $2.01 \pm 1.92 \mathrm{ng} / \mathrm{ml}$, and $1.17 \pm 0.17 \mathrm{ng} / \mathrm{ml}$ for the control group. Statistical analysis of results indicated that there was a significant increase in the mean value Bcl-2 in patients $\geq 50$ years than $<50$ years $(\mathrm{p}=<0.005)$, in postmenopausal than premenopausal $(\mathrm{p}=0.006)$, in $-\mathrm{ve}$ family history than +ve $(p=<0.005)$, in not used HRT than HRT used $(\mathrm{p}=<0.005)$ and in IDC patients than DCIS patients $(\mathrm{p}=<0.005)$. Also, it was found that there was a significant increase in the mean values of Bcl2 for grade III than grade I\&II $(p=0.05)$. We almost can say that the Bcl-2 values would increase with advanced grades of breast cancer. Also, it was observed that there was a significant increase in mean values of Bcl-2 in patients with -ve ER/PR and Her- 2 expression than +ve expression patients $(\mathrm{p}=<0.005)$.

Our results agreed with those of Mahdy et al. (2011) ${ }^{(14)}$ and Kallel-Bayoudh et al. (2011) ${ }^{(15)}$ who reported high levels of Bcl-2 in breast cancer patients before surgery compared with normal controls. The increase of $\mathrm{Bcl}-2$ in cancer cells points to a potentially critical role of this anti-apoptotic protein in breast cancer progression.
Overexpression of $\mathrm{Bcl}-2$ protein may serve as a determinator of advantageous cell survival in breast tumor cells, ultimately leading to tumor progression and metastases ${ }^{(16)}$. Also, Liu et al, (2014) ${ }^{(17)}$ found that the downregulation of $\mathrm{Bcl}-2$ in human breast cancer cells has been associated with a good prognosis.

Similar results obtained by Honma et al, (2015) ${ }^{(18)}$ demonstrated that $\mathrm{Bcl}-2$ is positive and significantly correlated with poor clinical outcomes in patients with ER-negative and PR-negative or triple-negative tumors. $\mathrm{Bcl}-2$ is positively independently predicted recurrence/mortality in hormone receptor-negative or triple-negative cases, but not in ER-positive and/or PR positive cases. It seems that the anti-apoptotic effect of Bcl-2, which usually correlates with poor clinical outcome or resistance to therapy in tumors other than breast cancer, is evident only in cases without hormone receptors and adjuvant therapy. They suggested that the anti-apoptotic nature of $\mathrm{Bcl}-2$ is exhibited under such conditions. The prognostic value of $\mathrm{Bcl}-2$ is more evident in postmenopausal women.

Tawfik et al. (2012) ${ }^{(19)}$ also found that the positivity of $\mathrm{Bcl}-2$ was in correlation with more aggressive tumor histology and longer overall survival in the non-triple-negative group whereas bcl-2 positivity was found to be related with shorter survival in a triple-negative group, interestingly.

Furthermore, Sezgin et al, (2014) (20) showed that Bcl-2 expression both in TripleNegative breast cancer (TNBC) and non-TNBC patients, and analysis of expression of Bcl- 2 may be meaningful for deciding treatment strategies for TNBC. They suggested that treatment strategies targeting Bcl-2 seem to be promising for this aggressive disease with no specific treatment. 
Berrak et al., (2016) ${ }^{(13)}$ reported that the increased expression level of $\mathrm{Bcl}-2$ was found correlated with drug resistance mechanism in various cancer cells including breast cancer cases.

In partial agreement with our study, Merino et al, (2015) (21) demonstrated that approximately $75 \%$ of primary breast cancers express high levels of BCL-2, with a predominance in ER-positive tumors: BCL-2 is overexpressed in nearly $85 \%$ of ER-positive tumors, 50\% of HER2- positive tumors, $41 \%$ of TNBCs and $19 \%$ of basal-like tumors. These findings appear to be consistent with gene expression profiling studies, where $\mathrm{Bcl}-2$ is predominantly expressed in ER-positive tumors. Interestingly, the frequency of BCL-2-positive tumors is lower (31\%) in BRCA1- associated cancers, compared with cancers without BRCA1 mutations, probably attributable to their triplenegative status.

However, other studies ${ }^{(22,23)}$ reported that Bcl-2 expression was positively correlated with ER and PR expression, but negatively correlated with HER2 expression, grade, and tumor size, confirming Bcl-2's association with favorable prognostic factors or differentiated markers.

Furthermore, Williams et al, (2015) (24) reported that $\mathrm{Bcl}-2$ expression frequently correlates with ER expression levels in ER+ breast cancers. Several studies have indicated that estrogen may upregulate Bcl-2, allowing for evasion of apoptosis ${ }^{25-}$ 27).

According to our study, we can conclude Breast cancer patients showed high serum levels of Bcl-2 as compared to normal controls, and a clear increase with the advanced grade of the tumor. Serum Bcl-2 can be considered a biomarker for breast cancer patients and could be used for monitoring the effect of chemotherapy on these patients. Our study may be applied for prevention and early intervention strategies in the Egyptian population.

\section{References:}

1. Phipps A, Mirick D, Li C, Davis S. Environmental and occupational exposures. In: Li C, ed. Springer New York; 2010:183-221.

2. Kerr JF, Wyllie AH, Currie AR. Apoptosis: a basic biological phenomenon with wideranging implications in tissue kinetics. $\mathrm{Br} \mathrm{J}$ Cancer 1972, 26:239-57.

3. Fadeel B, Orrenius S. Apoptosis: a basic biological phenomenon with wide-ranging implications in human disease (Review). J Intern Med 2005; 258:479-517.

4. Hanahan D, Weinberg RA. The hallmarks of cancer. Cell. 2000; 100:57-70.

5. Czabotar PE, Lessene G, Strasser A, Adams JM. Control of apoptosis by the BCL-2 protein family: implications for physiology and therapy. Nat Rev Mol Cell Biol. 2014;15:49-63.

6. Michelle MW, Rebecca SC. Bcl-2 family proteins in breast development and cancer: could Mcl-1 targeting overcome therapeutic resistance? Oncotarget. 2015;6:3519-30.

7. Walton KD, Wagner KU, Rucker EB, Shillingford JM, Miyoshi K, Hennighausen L. Conditional deletion of the bcl-x gene from mouse mammary epithelium results in accelerated apoptosis during involution but does not compromise cell function during lactation. Mech Dev. 2001; 109:281-93.

8. Harris JR, Morrow M, Lippman ME, Osborne CK. Disease of the Breast. Philadelphia, PA. 2010.

9. Veena VK, Kennedy K, Lakshmi P, Krishna R, Sakthivel N. Anti-leukemic, anti lung, and anti-breast cancer potential of the microbial polyketide 2, 4-diacetylphloroglucinol (DAPG) and its interaction with the metastatic proteins than the antiapoptotic $\mathrm{Bcl}-2$ proteins. Mol Cell Biochem. 2016;414:47-56.

10. Crawford A, Nahata R. Targeting Bcl-2 in Herceptin-Resistant Breast Cancer Cell Lines. Curr Pharmacogenomics. 2011; 9:184-90. 
11. Teijido O, Dejean L. Upregulation of Bcl-2 inhibits apoptosis-driven Bax insertion but favors Bax relocalization in mitochondria. FEBS Lett 2010;584:3305-10.

12. Hanahan D, Weinberg RA. The hallmarks of cancer. Cell. 2011; 144:646-74.

13. Berrak Ö, Akkoç Y, Arısan ED, Çoker-Gürkan A, Obakan-Yerlikaya P, Palavan Ünsal N. The inhibition of $\mathrm{PI} 3 \mathrm{~K}$ and $\mathrm{NF \kappa B}$ promoted curcumin-induced cell cycle arrest at $\mathrm{G} 2 / \mathrm{M}$ via altering polyamine metabolism in $\mathrm{Bcl}-2$ overexpressing MCF-7 breast cancer cells. Biomed Pharmacother. 2016;77:150-60.

14. Mahdy EM, Shousha WG, Ahmed HH, Metwally FM, Ramadan SS. Significance of serum HGF, Bcl-2 and nitric oxide in primary breast cancer. Nat Sci. 2011;9:34-41.

15. Kallel-Bayoudh I, Hassen HB, Khabir A, Boujelbene N, Daoud J, Frikha M, et al. Bcl-2 expression and triple-negative profile in breast carcinoma. Med Oncol. 2011;28:55-61.

16. Ebied SA, Abd El-Moneim NA, Hewala TI, Anwar MM, Rabi SM. The Diagnostic, Prognostic and Follow-up Value of Serum Bcl2, Bax and p53 Proteins in Breast Cancer Patients: A Comparison with Serum CA 15-3. Middle East J Cancer 2013; 4: 51-62.

17. Liu LH, Zhou YJ, Ding L, Zhang SZ, Sun J, Cao JG. Induction of apoptosis by VB1 in breast cancer cells: The role of reactive oxygen species and $\mathrm{Bcl}-2$ family proteins. International J Mol Med. 2014; 33: 423-30.

18. Honma N, Horii R, Ito Y, Shigehira S, Younes $\mathrm{M}$, Iwase $\mathrm{T}$, et al. Differences in clinical importance of Bcl-2 in breast cancer according to hormone receptors status or adjuvant endocrine therapy. BMC Cancer. 2015; 15:698.

19. Tawfik K, Kimler BF, Davis MK, Fan F, Tawfik O. Prognostic significance of Bcl-2 in invasive mammary carcinomas: a comparative clinicopathologic study between "triplenegative" and non-"triple-negative" tumors. Hum Pathol. 2012; 43, 23-30.

20. Sezgin AA, Yildirim M, Suren D, Yildiz M, Kaya V, Donem DU, et al. Expression of cyclooxygenase-2 and Bcl-2 in breast cancer and their relationship with triple-negative disease. J BUON. 2014;19:430-4.
21. Merino D, Lok SW, Visvader JE, Lindeman GJ. Targeting BCL-2 to enhance vulnerability to therapy in estrogen receptor-positive breast cancer. Oncogene. 2015;287: 1-11.

22. Silvestrini R, Veneroni S, Daidone MG, Benini E, Boracchi P, Mezzetti M, et al. The Bcl-2 protein: a prognostic indicator strongly related to $\mathrm{p} 53$ protein in lymph node-negative breast cancer patients. J Natl Cancer Inst.1994;86:499-504.

23. Daidone MG, Luisi A, Veneroni S, Benini E, Silvestrini R. Clinical studies of Bcl-2 and treatment benefit in breast cancer patients. Endocr Relat Cancer. 1999;6:61-8.

24. Williams MM, Cook RS. Bcl-2 family proteins in breast development and cancer: could Mcl-1 targeting overcome therapeutic resistance? Oncotarget. 2015;6:3519- 30.

25. Lewis-Wambi JS, Jordan VC. Estrogen regulation of apoptosis: how can one hormone stimulate and inhibit? Breast Cancer Res. 2009; 11: 206.

26. Koda KL, Koda M, Tomaszewski J, Jarzabek $\mathrm{K}$, Lotowska J. ER alpha and ER-beta expression in correlation with $\mathrm{Ki}-67, \mathrm{Bcl}-2$ and Bak in primary tumors and lymph node metastases of breast cancer: The effect of preoperative chemotherapy. Oncol Lett. 2010; 1 : 1067-71.

27. Schacter JL, Henson ES, Gibson SB. Estrogen Regulation of Anti-Apoptotic Bcl-2 Family Member Mcl-1 Expression in Breast Cancer Cells. PLoS ONE. 2014; 9: e100364. 